\title{
TARGETING MARKETS FOR EXPORT OF MACEDONIAN WINES TO THE EU
}

\author{
Snezana Ristevka-Jovanovska ${ }^{1}$, Blagica Sekovska², Ana Dimovska ${ }^{3}$ \\ *Corresponding author E-mail: bsekovska@fvm.ukim.edu.mk
}

A R T I C L E I N F O
Review Article
Received: 19 April 2018
Accepted: 04 September 2018
doi:10.5937/ekoPolj1803211R
UDC 663.21+339.564(497.7)(4-672 EU)

Keywords:

Macedonia, Macedonian wines, European Union, strategies, product

JEL: L11, L66, M31, P52

\section{A B S T R A C T}

The Republic of Macedonia has all the prerequisites for production of high quality wines and has great export potential, but Macedonian wines are almost unknown on the world wine market. Another problem is that most of the exported quantity is bulk wine, although in recent years the ratio between bulk and bottled wine started to change positively in terms of bottled wine. The wine market in the European Union is the most important export destination for Macedonian wines. Given the specificities of the wine market of individual member states, the aim of this paper is to select the countries in which the largest export of wine can be achieved. Macedonian wineries need to focus their export effort on the following markets: Germany, The Netherlands, Poland, Denmark and the Czech Republic. Methodology of desk research and market analysis is used for the conclusions.

(C) 2018 EA. All rights reserved.

\section{Introduction}

Wine is one of the symbols of Macedonia. The secret of Macedonian wines comes from the sun, which affects the taste of the grapes itself. Wine is not something new in this region, since wine is being made here from Ancient times. Vines have been cultivated 4,000 years ago and a large number of artifacts found on ancient sites confirms this ("Wine industry", 2015).

Grapes are a traditional and important agricultural crop for Macedonia. In rural areas, the cultivation of grapes engages the local population and has particular importance for the production of wine. Viticulture is probably the most important and strategic industry in the field of crop production (Economic chamber of Macedonia, 2005). In the period 2010-2016, the areas under vineyards were constant and range around 25,000 hectares, which is $0.4 \%$ of the world area with vineyards. Individuals $(80 \%)$ own most of them, and the remaining 20\% were privatized in the early 1990s (WOM, 2015).

1 Snezana Ristevka-Jovanovska, PhD, Full time professor, University St. Cyril and Methodius, Faculty of economics, E-mail: Snezana.ristevska-jovanovska@eccf.ukim.edu.mk

2 Blagica Sekovska, PhD, Full time professor, University St. Cyril and Methodius, Faculty of veterinary medicine, E-mail: bsekovska@fvm.ukim.edu.mk

3 Ana Dimovska, PhD, University St. Cyril and Methodius, Faculty of economics, Vostanicka 118-19, 1000 Skopje, Phone: +38975287888, E-mail: stankovska_ana@yahoo.com 
In Macedonia, 28 grape varieties are grown, and the presence of white and black varieties is equal to 50\% (WOM, 2017a). Vranec is the most common black variety, while Smederevka is most used white variety, but is unfortunately primarily used for the production of white wines of lower quality and distillation for brandy production (WOM, 2015, p.8).

According to climatic conditions, Macedonia is classified as one geographical area. It is considered a region for producing regional wine that is suitable for the entire territory of the country. Furthermore, this region is divided into 16 wine districts for production of quality wine. Each of them is characterized by different conditions and production capacity (Beleski, 2014).

In 2016, in Macedonia 75 wineries were registered (WOM, 2017a). The industry purchases from " 250 to 300 thousand tons of grapes per year depending on the harvest and produces 95-120 million liters, which directly affects the development of the country's agriculture. Grape and wine exports account for 17-20\% of the GDP in Macedonia and wine is the second most important export agricultural product, after tobacco, while wine exports contribute with foreign exchange inflows of 50 million euros a year" (WOM, 2017a, p.12).

Macedonian wineries have a total production capacity of 2.1 million hl, but use only half of it. The total bottling capacity, however, is about 650,000 hl per year, which is insufficient to cover the entire wine production in the country. Although insufficient capacity, bottling capacity remain unused because most of the wine is sold as a bulk (MAFWE, 2010). Almost 74\% of the produced wine in Macedonia in 2016 was intended for export. The key export destination in 2016 was the European Union (EU), which accounts for $57 \%$ of total exports in volume and $44 \%$ in value, followed by the Balkan countries with a share of $38 \%$ in volume and $45 \%$ in value (WOM, 2017b).

Since 2013, the ratio between bulk and bottled wine has begun to change in favor of exporting bottled wine. For the Macedonian wine industry, the structure of the exported wine is especially important, given that bottled wine is more profitable and although the quantities of bottled wine are smaller, they provide almost $50 \%$ of the value of the exported wine. Wineries that export wine to the EU by 2014 faced the problem of high tariffs for the amount exceeding the approved quotas for import of bulk wine, and in 2015 and 2016 the same thing happened with bottled wine (WOM, 2017a).

In order to analyze the macro-environment in which Macedonian wineries operate, it is necessary to analyze the political, economic, social and technological factors that influence the wine industry in the Republic of Macedonia.

The most prominent political factor is the stabilization of the political situation in the country in 2017 after long confrontations between political parties, since it is ultimately expected that it will positively affect the functioning of the entire economy, including the wine sector. Another factor is the permanent delay of the Euro-Atlantic integration of the country, mostly due to the name dispute between Greece and the Republic of Macedonia. This also affects the process of protecting geographical indications for wine in the Re- 
public of Macedonia. The state through the competent institutions has a great influence in determining the price for the purchase of grapes during the harvest period. The goal is protection of vinegrowers, and this measure is used in daily political campaigns.

The signed Protocol for export of Macedonian wine to the EU under the Stabilization and Association Agreement with the EU since 2004 is an economic factor of great importance. It enables the export of large quantities of wine to the EU without customs duties, which makes Macedonian wine competitive on the EU market. Other economic factors are:

1) Determining viticulture and wine production as a strategic branch of the Republic of Macedonia, which opens up opportunities for vinegrowers and wineries to use the funds from the IPARD Program for Support of Agriculture and Rural Development,

2) The Government additionally provides financial support for wine exporters primarily through support of marketing and promotional activities,

3) Domestic production of wine is still significant, especially in the smaller towns along Vardar River,

4) Protection of domestic wine producers with a customs rate for importing wine, which contributes to very limited distribution of foreign wines on the domestic market; and

5) There is not excise duty for the wine as an alcoholic beverage.

Social factor affecting the wine industry is the low purchasing power of the population that limits consumption of high quality wine only on special occasions. In Macedonia, the wine culture is still at a very low level and continues the tradition of production and consumption of domestic poor quality wine, especially outside Skopje. The emigration of young educated people from the country is increasing and this group of people is leading the trend of consumption of high quality wine. Another factor is the change in the structure of the available labor during the harvest period, primarily due to the opening of the "Dräxlmaier" factory in Kavadarci where a large number of workers were employed and the wineries started to face the problem of providing the necessary workforce in the period the harvest.

From the technological aspect, the significance of large investments in modernization of production capacities and introduction of the latest technologies in wine production should be emphasized. Management of the vineyards has been improved by introducing new techniques for growing grapes and reducing the yield, in order to increase the quality of the grapes and thus the final product. No less important are the increased investments in marketing of products by Macedonian wineries, as well as following new trends in packaging, bottle closure and labeling. Another change that is more recent is the increased awareness of the wineries for specialized wine educations of their employees in order to improve the skills in all segments of operations.

Through consideration of these factors, we get a perception of how the Macedonian wine industry works, as well as the factors that can appear as an opportunity or threat for all involved parties in the wine business. 
The most important competitors of the Macedonian wine are the countries of Southeast Europe and the countries that are newcomers on the global wine market. The primary competitors of Macedonian wines are Moldova, Georgia, Slovenia, Croatia, Bulgaria, Greece and Romania (WOM, 2015).

Macedonia has several unique selling propositions which can use for differentiation from other competitors. First is that it is a new country from the Old World or more precisely a country from the Old World with a new vision. As a wine country, Macedonia is at the same time very young and very old. Besides this advantage, Macedonia has a favorable microclimate and rich soil for growing grapes. No less significant are local varieties, due to the high concentration of resveratrol in the red wines and caftaric acid in the white wines. Macedonian wineries have modern wine processing facilities and they are oriented towards varietal labeling. Finally yet importantly, Macedonian wines continuously win awards and recognitions at international wine competitions (WOM, 2015).

\section{Materials and methodology}

In order to select target markets in the EU for Macedonian wines, desk research and market analysis were used. All available sources of information were taken into account: 1) information from Wines of Macedonia (WOM) association about export of Macedonian wines in EU countries; 2) vine and wine sector strategy from Ministry of Agriculture, Forestry and Water Economy (MAFWE); 3) information for the production and consumption of EU countries from Wine Institute; 4) interviews with export managers from Macedonian wineries; 5) data from Trade map for import of wine in EU countries.

Also, a valuable information were used from CBI Market Intelligence about trends in the wine industries of the target markets. This information was crucial for defining future activities on those markets.

\section{Results}

The paper analyzes seven criteria for selecting target markets in EU for Macedonian wines:

1. Export volumes of bulk wine from Macedonia to EU-28 (2016)

2. Export volumes of bottled wine from Macedonia to EU-28 (2016)

3. Per capita wine consumption in EU-28 (2014)

4. Wine production in the EU-28 (2015)

5. Import of bulk wine in EU-28 (2016)

6. Import of bottled wine in EU-28 (2016)

7. Import of bottled wine in EU-28 from the countries of South-East Europe (2016)

All EU-28 Member States are given points for each criterion in order to obtain the total number of points per country. Less importance is given to the bulk wine compared to 
the bottled, because the goal is export of bottled wine. Therefore, criteria 1 and 5 are given less importance and scoring is done on a scale from one to five, and on the other criteria from six to ten points.

The first two criteria (Table 1) include data on export of Macedonian wine in 2016 and show the most important export markets in the EU. This criteria show the perspective of Macedonian wine in certain markets, as well as the importance of the markets especially for exporting bottled wine. That is why the highest points are given to the countries where Macedonia exports the most wine.

Table 1. Export of Macedonian bulk and bottled wine to the EU-28 in $2016^{4}$

\begin{tabular}{|c|c|c|c|c|c|c|c|c|}
\hline \multirow[b]{2}{*}{ Country } & \multicolumn{4}{|c|}{ Criteria 1 - Bulk wine } & \multicolumn{4}{|c|}{ Criteria 2 - Bottled wine } \\
\hline & Volume (liters) & $\begin{array}{l}\text { Value } \\
\text { (euros) }\end{array}$ & 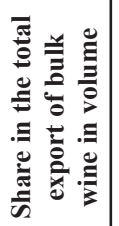 & 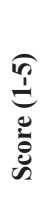 & Volume (liters) & $\begin{array}{l}\text { Value } \\
\text { (euros) }\end{array}$ & 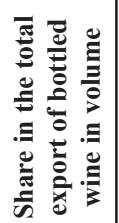 & 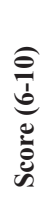 \\
\hline Austria & $/$ & / & $/$ & / & 3,300 & 8,462 & $0 \%$ & 6 \\
\hline Belgium & $/$ & 1 & 1 & 1 & 13,500 & 35,310 & $0 \%$ & 6 \\
\hline Bulgaria & 11,400 & 4,786 & $0 \%$ & 1 & 491,100 & 499,557 & $4 \%$ & 6 \\
\hline Croatia & $5,532,600$ & $3,838,198$ & $25 \%$ & 3 & $6,939,700$ & $5,150,436$ & $59 \%$ & 9 \\
\hline Cyprus & $/$ & 1 & & I & 2,900 & 2,064 & $0 \%$ & 6 \\
\hline Czech Republic & 503,000 & 248,996 & $2 \%$ & 1 & 58,000 & 82,007 & $0 \%$ & 6 \\
\hline Denmark & 1,000 & 7,959 & $0 \%$ & 1 & 17,900 & 133,995 & $0 \%$ & 6 \\
\hline Estonia & $/$ & $/$ & $/$ & l & $/$ & $/$ & $/$ & / \\
\hline Finland & 1 & 1 & 1 & 1 & 1 & 1 & 1 & 1 \\
\hline France & $/$ & 1 & $/$ & 1 & 2,500 & 9,609 & $0 \%$ & 6 \\
\hline Germany & $15,523,100$ & $6,540,681$ & $69 \%$ & 5 & 589,000 & 804,330 & $5 \%$ & 6 \\
\hline Greece & 1 & 1 & 1 & 1 & $/$ & $/$ & 1 & 1 \\
\hline Hungary & $/$ & / & $/$ & / & 1,300 & 9,978 & $0 \%$ & 6 \\
\hline Ireland & $/$ & 1 & $/$ & 1 & $/$ & $/$ & 1 & I \\
\hline Italy & $/$ & 1 & $/$ & I & 38,900 & 94,457 & $0 \%$ & 6 \\
\hline Slovakia & $/$ & 1 & $/$ & / & 12,400 & 33,892 & $0 \%$ & 6 \\
\hline Slovenia & 588,500 & 336,619 & $3 \%$ & 1 & $3,334,000$ & $1,965,224$ & $28 \%$ & 8 \\
\hline Lithuania & 5,500 & 4,801 & $0 \%$ & 1 & 16,500 & 27,214 & $0 \%$ & 6 \\
\hline
\end{tabular}

4 The points are given in the following way:

Criteria 1 - Export of bulk wine from Macedonia to EU-28: 0-10\% = 1 point; $10-20 \%=2$ points; $20-40 \%=3$ points; $40-60 \%=4$ points; $60-100 \%=5$ points;

Criteria 2 - Export of bulk wine from Macedonia to EU-28: 0-10\% = 6 points; $10-20 \%=7$ points; $20-40 \%=8$ points; $40-60 \%=9$ points; $60-100 \%=10$ points 


\begin{tabular}{|c|c|c|c|c|c|c|c|c|}
\hline \multirow[b]{2}{*}{ Country } & \multicolumn{4}{|c|}{ Criteria 1 - Bulk wine } & \multicolumn{4}{|c|}{ Criteria 2 - Bottled wine } \\
\hline & Volume (liters) & $\begin{array}{l}\text { Value } \\
\text { (euros) }\end{array}$ & 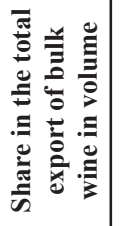 & 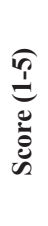 & Volume (liters) & $\begin{array}{l}\text { Value } \\
\text { (euros) }\end{array}$ & 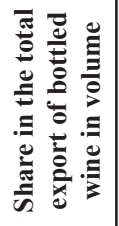 & 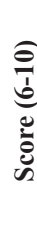 \\
\hline Latvia & $/$ & 1 & 1 & 1 & 71,300 & 88,754 & $1 \%$ & 6 \\
\hline Luxembourg & $/$ & / & $/$ & l & $/$ & $/$ & 1 & / \\
\hline Netherlands & 300 & 890 & $0 \%$ & 1 & 62,000 & 146,456 & $1 \%$ & 6 \\
\hline Poland & 175,000 & 71,772 & $1 \%$ & 1 & 134,000 & 106,499 & $1 \%$ & 6 \\
\hline Portugal & $/$ & $/$ & $/$ & 1 & 1 & 1 & 1 & / \\
\hline Romania & 98,700 & 46,679 & $0 \%$ & 1 & $/$ & 1 & 1 & l \\
\hline Spain & 1 & 1 & 1 & 1 & $/$ & $/$ & $/$ & 1 \\
\hline Sweden & 1 & 1 & 1 & 1 & 21,800 & 58,050 & $0 \%$ & 6 \\
\hline Malta & $/$ & / & $/$ & 1 & / & $/$ & 1 & / \\
\hline United Kingdom & $/$ & / & $/$ & / & 51,500 & 92,506 & $0 \%$ & 6 \\
\hline Total EU-28 & $22,439,100$ & $11,101,381$ & $100 \%$ & & $11,861,600$ & $9,348,800$ & $100 \%$ & \\
\hline
\end{tabular}

Source: WOM, 2017c

The third selection criteria reveal the most attractive markets in terms of wine per capita consumption. Therefore, high points are given to countries with relatively high per capita consumption, assuming that these countries have the capacity for bigger wine imports in order to meet the needs of consumers on the domestic market.

On the other hand, country production volumes helps us to determinate the most difficult markets to penetrate. Those are countries where production of wine highly exceeds (2-3 times) the domestic wine consumption, meaning that the wine industries of these countries are highly developed, producing all type of wine and fully satisfy the domestic demand. Such markets are serious hurdle for foreign competition and should be avoided. That is why countries that have lower production are given more points, and vice versa. Criteria 3 and 4 are covered in Table 2. 
Table 2. Wine consumption per capita in the EU-28 in 2014 and wine production in EU-28 in $2015^{5}$

\begin{tabular}{|c|c|c|c|c|}
\hline \multirow[b]{2}{*}{ Country } & \multicolumn{2}{|c|}{ Criteria 3} & \multicolumn{2}{|c|}{ Criteria 4} \\
\hline & $\begin{array}{c}\text { Wine } \\
\text { consumption } \\
\text { per capita } \\
\text { (liters) }\end{array}$ & Score $(6-10)$ & $\begin{array}{c}\text { Wine } \\
\text { production } \\
\text { (in million } \\
\text { liters) }\end{array}$ & Score $(6-10)$ \\
\hline Austria & 30.66 & 9 & 230.0 & 10 \\
\hline Belgium & 23.07 & 8 & 3.0 & 10 \\
\hline Bulgaria & 20.60 & 8 & 191.3 & 10 \\
\hline Croatia & 44.20 & 10 & 168.0 & 10 \\
\hline Cyprus & 14.94 & 7 & 10.8 & 10 \\
\hline Czech Republic & 19.65 & 7 & 45.0 & 10 \\
\hline Denmark & 14.05 & 7 & 1 & 10 \\
\hline Estonia & 2.79 & 6 & 1 & 10 \\
\hline Finland & 4.45 & 6 & 1 & 10 \\
\hline France & 42.51 & 10 & $4,750.0$ & 6 \\
\hline Germany & 24.84 & 8 & 890.0 & 9 \\
\hline Greece & 27.86 & 8 & 270.0 & 10 \\
\hline Hungary & 24.10 & 8 & 290.0 & 10 \\
\hline Ireland & 5.46 & 6 & 1 & 10 \\
\hline Italy & 33.30 & 9 & $4,950.0$ & 6 \\
\hline Slovakia & 15.50 & 7 & 37.3 & 10 \\
\hline Slovenia & 44.07 & 10 & 75.0 & 10 \\
\hline Lithuania & 1.11 & 6 & 1 & 10 \\
\hline Latvia & 3.19 & 6 & 1 & 10 \\
\hline Luxembourg & 9.82 & 6 & 10.1 & 10 \\
\hline Netherlands & 18.33 & 7 & 1 & 10 \\
\hline Poland & 0.42 & 6 & 1 & 10 \\
\hline Portugal & 41.74 & 10 & 670.0 & 9 \\
\hline Romania & 24.26 & 8 & 350.0 & 10 \\
\hline Spain & 21.26 & 8 & $3,720.0$ & 6 \\
\hline Sweden & 26.00 & 8 & 1 & 10 \\
\hline Malta & 23.18 & 8 & 2.2 & 10 \\
\hline United Kingdom & 21.99 & 8 & 1 & 10 \\
\hline
\end{tabular}

Source: Wine Institute, 2015, 2017

5 The points are given in the following way:

Criteria $3-0-10$ liters $=6$ points; $10.1-20$ liters $=7$ points; $20.1-30$ liters $=8$ points; $30.1-40$ liters $=9$ points; $40.1-50$ liters $=10$ points.

Criteria 4 - In million liters: $0-500=10$ points; $501-1.500=9$ points; $1.501-2.500=8$ points; $2.501-3.500=7$ points; $>3.500=6$ points 
Criteria 5 and 6 relate to total wine imports (bulk and bottled) in the European Union in 2016 (please see below Table 3).

Table 3. Import of bulk and bottled wine in EU-28 in $2016^{6}$

\begin{tabular}{|c|c|c|c|c|c|c|}
\hline \multirow[b]{2}{*}{ Country } & \multicolumn{3}{|c|}{ Criteria 5} & \multicolumn{3}{|c|}{ Criteria 6} \\
\hline & 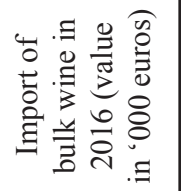 & 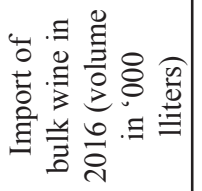 & $\begin{array}{l}\text { Score } \\
(1-5)\end{array}$ & 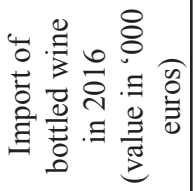 & 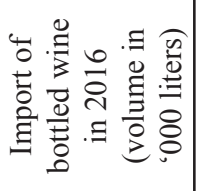 & $\begin{array}{l}\text { Score } \\
(6-10)\end{array}$ \\
\hline Austria & 15,858 & 25,641 & 1 & 120,203 & 39,969 & 6 \\
\hline Belgium & 97,838 & 84,110 & 1 & 576,768 & 172,447 & 7 \\
\hline Bulgaria & 1,905 & 3,697 & 1 & 11,009 & 3,259 & 6 \\
\hline Croatia & 10,210 & 18,335 & 1 & 13,992 & 11,363 & 6 \\
\hline Cyprus & 771 & 954 & 1 & 16,164 & 6,782 & 6 \\
\hline Czech Republic & 51,097 & 98,410 & 1 & 109,645 & 64,581 & 6 \\
\hline Denmark & 94,786 & 77,690 & 1 & 423,039 & 89,729 & 6 \\
\hline Estonia & 11,046 & 7,304 & 1 & 38,099 & 12,385 & 6 \\
\hline Finland & 38,527 & 30,020 & 1 & 125,397 & 38,702 & 6 \\
\hline France & 252,383 & 622,754 & 5 & 411,213 & 120,788 & 7 \\
\hline Germany & 488,372 & 851,849 & 5 & $1,581,641$ & 546,306 & 9 \\
\hline Greece & 3,519 & 7,407 & 1 & 12,067 & 7,262 & 6 \\
\hline Hungary & 6,001 & 14,398 & 1 & 7,489 & 3,846 & 6 \\
\hline Ireland & 4,708 & 1,558 & 1 & 244,749 & 112,744 & 7 \\
\hline Italy & 91,522 & 137,349 & 2 & 61,613 & 22,627 & 6 \\
\hline Slovakia & 12,950 & 31,697 & 1 & 33,721 & 30,130 & 6 \\
\hline Slovenia & 2,974 & 0 & 1 & 7,124 & 6,538 & 6 \\
\hline Lithuania & 9,475 & 19,232 & 1 & 129,739 & 57,715 & 6 \\
\hline Latvia & 1,968 & 1,512 & 1 & 45,443 & 20,388 & 6 \\
\hline Luxembourg & 5,674 & 8,616 & 1 & 65,413 & 18,082 & 6 \\
\hline Netherlands & 55,457 & 60,421 & 1 & 816,325 & 305,819 & 8 \\
\hline Poland & 12,691 & 20,947 & 1 & 191,787 & 83,761 & 6 \\
\hline Portugal & 51,997 & 127,479 & 2 & 30,391 & 40,309 & 6 \\
\hline Romania & 14,617 & 35,459 & 1 & 19,911 & 10,996 & 6 \\
\hline Spain & 13,709 & 25,213 & 1 & 69,095 & 22,667 & 6 \\
\hline Sweden & 172,281 & 72,291 & 1 & 361,294 & 58,934 & 6 \\
\hline Malta & 484 & 979 & 1 & 14,171 & 5,588 & 6 \\
\hline United Kingdom & 485,314 & 482,107 & 4 & $2,395,177$ & 799,431 & 10 \\
\hline
\end{tabular}

Source: Trademap, 2017

6 Criteria $5-0-100.000$ ('000 liters) $=1$ point; $100.000-200.000$ liters $=2$ points; $200.000-400.000$ liters $=3$ points; $400.000-600.000$ liters $=4$ points; $600.000-1.000 .000$ liters $=5$ points Criteria $6-0-100.000$ ('000 liters) $=6$ points; $100.000-200.000$ liters $=7$ points; $200.000-400.000$ liters $=8$ points; $400.000-600.000$ liters $=9$ points; $600.000-1.000 .000$ liters $=10$ points 
For the import of bulk wine in EU-28 (criteria 5) scoring is done on a scale from 1 to 5 , because this criteria is considered less relevant than import of bottled wines and it brings fewer points in the final selection. On the other hand, for import of bottled wine in EU-28 scoring is done on a scale from 6 to 10, because this criteria is considered more relevant than import of bulk wine.

In addition, the last criteria refers to the import of bottled wine into the EU from the countries of Southeastern Europe: Republic of Macedonia, Croatia, Bulgaria, Montenegro, Albania, Serbia, Slovenia, Bosnia and Herzegovina, Greece, Romania, Hungary, Moldova, Georgia and Armenia. The goal is to see the openness of EU countries to import wine from this group of countries, which includes Macedonia (Table 4).

Table 4. Import of bottled wine in EU-28 from Southeast Europe in $2016^{7}$

\begin{tabular}{|c|c|c|c|c|}
\hline Country & 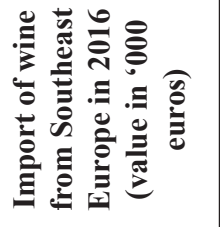 & 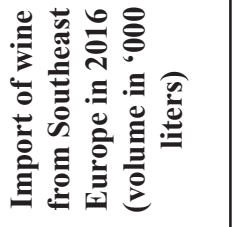 & 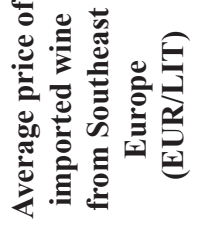 & 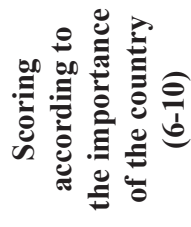 \\
\hline Austria & 1,957 & 817 & 2.40 & 6 \\
\hline Belgium & 3,331 & 1,346 & 2.47 & 6 \\
\hline Bulgaria & 275 & 119 & 2.31 & 6 \\
\hline Croatia & 8,359 & 9,519 & 0.88 & 9 \\
\hline Cyprus & 5,326 & 1,826 & 2.92 & 6 \\
\hline Czech Republic & 16,940 & 13,215 & 1.28 & 10 \\
\hline Denmark & 600 & 149 & 4.03 & 6 \\
\hline Estonia & 2,702 & 1,074 & 2.52 & 6 \\
\hline Finland & 480 & 152 & 3.16 & 6 \\
\hline France & 1,531 & 549 & 2.79 & 6 \\
\hline Germany & 26,741 & 12,591 & 2.12 & 10 \\
\hline Greece & 186 & 156 & 1.19 & 6 \\
\hline Hungary & 477 & 218 & 2.19 & 6 \\
\hline Ireland & 506 & 244 & 2.07 & 6 \\
\hline Italy & 3,050 & 1,143 & 2.67 & 6 \\
\hline Slovakia & 11,617 & 17,485 & 0.66 & 10 \\
\hline Slovenia & 2,727 & 4,062 & 0.67 & 8 \\
\hline
\end{tabular}

7 Criteria 7 - Scoring is done on a scale from 6 to 10 . The points are given in the following way:

0-2.000 ('000 liters) $=6$ points; $2.000-4.000$ liters $=7$ points; $4.000-6.000$ liters $=8$ points; $6.000-10.000$ liters $=9$ points; $10.000-20.000$ liters $=10$ points 


\begin{tabular}{|c|c|c|c|c|}
\hline Country & 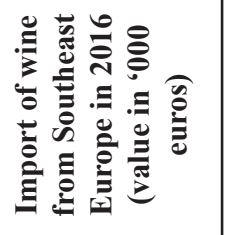 & 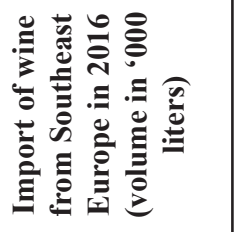 & 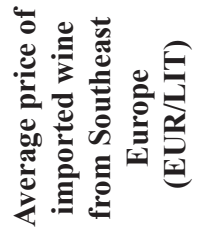 & 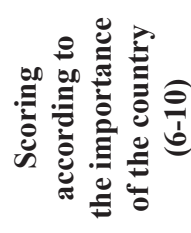 \\
\hline Lithuania & 2,967 & 1,438 & 2.06 & 6 \\
\hline Latvia & 4,409 & 1,971 & 2.24 & 6 \\
\hline Luxembourg & 92 & 39 & 2.36 & 6 \\
\hline Netherlands & 3,673 & 1,671 & 2.20 & 6 \\
\hline Poland & 27,003 & 16,380 & 1.65 & 10 \\
\hline Portugal & 17 & 8 & 2.13 & 6 \\
\hline Romania & 7,146 & 5,902 & 1.21 & 8 \\
\hline Spain & 1,636 & 335 & 4.88 & 6 \\
\hline Sweden & 1,236 & 379 & 3.26 & 6 \\
\hline Malta & 4 & 2 & 0.00 & 6 \\
\hline United Kingdom & 22,627 & 12,624 & 1.79 & 10 \\
\hline
\end{tabular}

Source: Trade map, 2017

In the process of selection of target markets, the opinion of the Macedonian export managers is taken into consideration, given that they have the greatest knowledge about the difficulties in entering certain markets and the obstacles they face. Additional 10 points are given to the markets selected by the export managers (in Table 5). They are most familiar with the conditions of each market, demand, competition, importers, expected future growth, the possibility of penetration, as well as the desire of consumers to try new wines. Although certain markets have significant wine imports, they are really difficult to enter for countries that are new to the world wine market such as Macedonia.

Table 5. Overall evaluation of target markets for the Macedonian wines in EU

\begin{tabular}{|l|c|c|c|c|c|c|c|c|c|c|}
\hline \multirow{2}{*}{ Country } & \multicolumn{7}{|c|}{ Criteria } & Points & $\begin{array}{c}\text { Opinion of } \\
\text { from the } \\
\text { Macedonian } \\
\text { exiteria }\end{array}$ & $\begin{array}{c}\text { Total } \\
\text { export } \\
\text { managers }\end{array}$ \\
\cline { 2 - 12 } & 1 & 2 & 3 & 4 & 5 & 6 & 7 & & 38 \\
\hline Austria & 1 & 6 & 8 & 10 & 1 & 6 & 6 & 38 & & 39 \\
\hline Belgium & 1 & 6 & 8 & 10 & 1 & 7 & 6 & 39 & & 38 \\
\hline Bulgaria & 1 & 6 & 8 & 10 & 1 & 6 & 6 & 38 & & 49 \\
\hline Croatia & 3 & 10 & 10 & 10 & 1 & 6 & 9 & 49 & & 37 \\
\hline Cyprus & 1 & 6 & 7 & 10 & 1 & 6 & 6 & 37 & & $\mathbf{5 1}$ \\
\hline Czech Republic & $\mathbf{1}$ & $\mathbf{6}$ & $\mathbf{7}$ & $\mathbf{1 0}$ & $\mathbf{1}$ & $\mathbf{6}$ & $\mathbf{1 0}$ & $\mathbf{4 1}$ & $\mathbf{1 0}$ & 47 \\
\hline Denmark & 1 & 6 & 7 & 10 & 1 & 6 & 6 & 37 & 10 & 47 \\
\hline
\end{tabular}




\begin{tabular}{|c|c|c|c|c|c|c|c|c|c|c|}
\hline \multirow{2}{*}{ Country } & \multicolumn{7}{|c|}{ Criteria } & \multirow{2}{*}{$\begin{array}{l}\text { Points } \\
\text { from the } \\
\text { criteria }\end{array}$} & \multirow{2}{*}{$\begin{array}{c}\text { Opinion of } \\
\text { Macedonian } \\
\text { export } \\
\text { managers }\end{array}$} & \multirow{2}{*}{$\begin{array}{l}\text { Total } \\
\text { score }\end{array}$} \\
\hline & 1 & 2 & 3 & 4 & 5 & 6 & 7 & & & \\
\hline Estonia & 1 & 6 & 6 & 10 & 1 & 6 & 6 & 36 & & 36 \\
\hline Finland & 1 & 6 & 6 & 10 & 1 & 6 & 6 & 36 & & 36 \\
\hline France & 1 & 6 & 10 & 6 & 5 & 7 & 6 & 41 & & 41 \\
\hline Germany & 5 & 6 & 8 & 9 & 5 & 9 & 10 & 52 & 10 & 62 \\
\hline Greece & 1 & 6 & 8 & 10 & 1 & 6 & 6 & 38 & & 38 \\
\hline Hungary & 1 & 6 & 8 & 10 & 1 & 6 & 6 & 38 & & 38 \\
\hline Ireland & 1 & 6 & 6 & 10 & 1 & 7 & 6 & 37 & & 37 \\
\hline Italy & 1 & 6 & 9 & 6 & 2 & 6 & 6 & 36 & & 36 \\
\hline Slovakia & 1 & 6 & 7 & 10 & 1 & 6 & 10 & 41 & & 41 \\
\hline Slovenia & 1 & 8 & 10 & 10 & 1 & 6 & 8 & 44 & & 44 \\
\hline Lithuania & 1 & 6 & 6 & 10 & 1 & 6 & 6 & 36 & & 36 \\
\hline Latvia & 1 & 6 & 6 & 10 & 1 & 6 & 6 & 36 & & 36 \\
\hline Luxembourg & 1 & 6 & 6 & 10 & 1 & 6 & 6 & 36 & & 36 \\
\hline Netherlands & 1 & 6 & 7 & 10 & 1 & 8 & 6 & 39 & 10 & 49 \\
\hline Poland & 1 & 6 & 6 & 10 & 1 & 6 & 10 & 40 & 10 & 50 \\
\hline Portugal & 1 & 6 & 10 & 9 & 2 & 6 & 6 & 40 & & 40 \\
\hline Romania & 1 & 6 & 8 & 10 & 1 & 6 & 8 & 40 & & 40 \\
\hline Spain & 1 & 6 & 8 & 6 & 1 & 6 & 6 & 34 & & 34 \\
\hline Sweden & 1 & 6 & 8 & 10 & 1 & 6 & 6 & 38 & & 38 \\
\hline Malta & 1 & 6 & 8 & 10 & 1 & 6 & 6 & 38 & & 38 \\
\hline United Kingdom & 1 & 6 & 8 & 10 & 4 & 10 & 10 & 49 & 10 & 59 \\
\hline
\end{tabular}

Source: Authors' evaluation

\section{Results and discussions}

According to the previously mentioned criteria, 5 (five) countries were selected as target markets for Macedonian wines:

1. Germany is the largest export market for Macedonian bulk wine(WOM, 2017c). On this market, Macedonia is perceived as a producer of cheap low-quality wines. Germans prefer imported red wines and do not tax the wine as a product, only sparkling wines (Lieberz, 2015; CBI Market Intelligence, 2016a). However, due to the current low prices of Macedonian wineries on the market, they will not be able to drastically increase export prices in the near future (WOM, 2017d). Initially, promotional activities in Germany should be directed to B2B contacts in order to change the perception of German importers for the value of Macedonian wines. Sales in Germany should be directed to the northern 
part of the country, given that in the southern part a satisfactory level of local production is achieved (CBI Market Intelligence, 2016b).

2. The Netherlands is one of the countries where Macedonia has the lowest export of bulk and bottled wine, but is open to importing wine from the countries of Southeast Europe. Wine taxes are continuously growing, and on the other hand, the Dutch are price sensitive and tend to purchase in stores at lower prices (CBI Market Intelligence, 2016c). Therefore, it is best to taka as a benchmark the prices of the competitive wines on the market. In the Netherlands, there is almost no domestic production, and this is not expected to change in the near future (CBI Market Intelligence, 2016d). The focus should be placed on public relations, presence of significant regional fairs and manifestations and communication with target groups: Dutch tourists who visit Macedonia, wine experts. In terms of distribution, the focus should be placed on supermarkets, as consumers usually buy wine there.

3. Poland is a market that has not been given special attention so far, and has great potential for increasing exports. Although this wine market is one of the least developed within the EU, wine sales are experiencing a boom (CBI Market Intelligence, 2016e). Polish consumers are much more familiar with Macedonian wines because of the geographical closeness with Macedonia. An additional advantage is the preference of red wines from Polish consumers, and it is an opportunity for Macedonian wineries to promote the autochthonous Vranec variety. Due to the low standard of life in this country, as well as the undeveloped wine culture, it is not recommended to increase export prices, but to use prices for initial entry on the market. At the same time, Macedonian wineries need to work on educating consumers about wine, highlighting its positive aspects, organizing tastings and BTL-promotions, as well as taking part in regional festivals and fairs. It is recommended direct export for offtrade, and indirect in on-trade. In both cases, it's necessary to pay attention on education of the management teams in the markets and restaurants, as well as organizing a visit to the Macedonian wineries.

4. Denmark has a highly fragmented wine market and has the highest average number of wine importers per capita, which means that there is intense competition on the market (Meininger's WBI, 2013). More recently, the Danes are increasingly oriented towards the consumption of wines from traditional European countries, and are more reserved for the countries of the New World (CBI Market Intelligence, 2016f). In 2016, Macedonia made very little export of bottled wines in this country, and in the same year, it did not export any bulk wine. Consumers follow fashion trends in the wine industry and they are increasingly oriented towards environmentally friendly products. For Macedonian wines it is positive that local wine production is insignificant, and negative that taxation in Denmark is quite high (CBI Market Intelligence, 2016f). Despite this, in 2016, Macedonian wines achieved a high average 
export price in Denmark and it is recommended to use the strategy of price matching with the competition (WOM, 2017d). Activities in this market should be focused on BTL activities and organizing events, visits and tastings, as well as presenting Macedonia as a wine country. In distribution, the focus should be placed on on-trade which is expected to grow in the future, although now is a small segment of the market.

5. The Czech Republic is a market that, due to its geographical closeness with Macedonia, provides better acquaintance of Czech consumers with Macedonian wines. Although the symbol of this country is beer, wine has gained great popularity in recent years. Most of the wine is imported from EU member countries (CBI Market Intelligence, 2016g). In 2016 bottled Macedonian wine has very little participation in the total exports in the Czech Republic, therefore Macedonian wineries need to use a strategy of repositioning the existing products. Taxation is much lower than other developed wine markets in the EU, which contributes to achieving lower prices (CBI Market Intelligence, 2016g). The export prices on this market should not be increased given the lower purchasing power of Czech consumers (CBI Market Intelligence, 2016h). In this country there are minimal restrictions on the promotion of wine in the media and this allows to use ATL advertising in specialized wine media (CBI Market Intelligence, 2016g). Another way to promote is by educating Czech consumers about wine as a product. The distribution can be directed both to off-trade (indirectly through importers) or specialized stores that sell premium wines.

\section{Conclusions}

Studies that analyze the decision-making process by consumers when purchasing wine constantly indicate that in the wide range of brands on the shelf, the origin of the brand plays the role of qualitative differentiation. For this reason, it is of crucial importance for Macedonia to focus on strengthening the image of the country and increasing the export of high quality wines in the premium segment. Hence, the possibility of increasing exports depends primarily on the success of positioning and strengthening not only the image of the country, but also the brand "Wines of Macedonia".

One of the key challenges facing the Macedonian wine industry when it comes to foreign markets is the general unrecognizability of Macedonia as a wine country. It is necessary to invest serious efforts and funds for image building and for the promotion of the Republic of Macedonia as a producer of quality wine and for overcoming the perception as a county producing bulk wines. That's why using the common wine brand is of particular importance with targeted and joint promotions and appearance of the wineries to the foreign markets.

In recent years the ratio between bulk and bottled wine started to change positively in terms of bottled wine. 
The European Union is not only the biggest producer, consumer and trader of wine in the world, it is also the most important export market for Macedonian wines. But there are differences in the wine market development of the EU Members and the behavior and lifestyle of consumers are also different. Therefore, a selection of five markets (countries) that offer the greatest opportunities for the Macedonian wineries is done: Germany, the Netherlands, Poland, Denmark and the Czech Republic.

Only with the joint appearance of the wineries, creating a common brand and a defined national strategy for target markets, Republic of Macedonia can expect an increase in EU imports of wine. Otherwise, the individual success of certain wineries on certain markets will be valorization only for their commercial achievements.

\section{Conflict of interests}

The authors declare no conflict of interest.

\section{References}

1. Beleski, K. (2014). Wines of Macedonia: A short guide to Macedonian wines and wineries. Skopje. Republic of Macedonia: Treto uvo

2. CBI Market Intelligence (2016a). CBI Trends: Wine in Germany. Retrieved from https://www.cbi.eu/sites/default/files/market_information/researches/ trends-germany-wine-2016.pdf

3. CBI Market Intelligence (2016b). CBI Competition: Wine in Germany. Retrieved from https://www.cbi.eu/sites/default/files/market_information/researches/competition-germany-wine-2016.pdf

4. CBI Market Intelligence (2016c). CBI Trends: Wine in Netherlands. Retrieved from https://www.cbi.eu/sites/default/files/market_information/researches/ trends-netherlands-wine-2016.pdf

5. CBI Market Intelligence (2016d). CBI Competition: Wine in Netherlands. Retrieved from https://www.cbi.eu/sites/default/files/market_information/researches/competition-netherlands-wine-2016.pdf

6. CBI Market Intelligence (2016e). CBI Trends: Wine in Poland. Retrieved from https://www.cbi.eu/sites/default/files/market_information/researches/trendspoland-wine-2016.pdf

7. CBI Market Intelligence (2016f). CBI Trends: Wine in Denmark. Retrieved from https://www.cbi.eu/sites/default/files/market_information/researches/ trends-denmark-wine-2016.pdf

8. CBI Market Intelligence (2016g). CBI Trends: Wine in the Czech Republic. Retrieved from https://www.cbi.eu/sites/default/files/market_information/researches/trends-czech-republic-wine-2016.pdf 
9. CBI Market Intelligence (2016h). CBI Competition: Wine in the Czech Republic. Retrieved from https://www.cbi.eu/sites/default/files/market_information/ researches/competition-czech-republic-wine-2016.pdf

10. Economic chamber of Macedonia (2005). Production of grapes and wine in the Republic of Macedonia. Retrieved from http:/www.mchamber.org.mk/ (S(yp5ani5545p10aioww010245))/default.aspx?1Id=1\&mId=130\&smId=14

11. Lieberz, S. (2015). Overview on the German Wine Sector. GAIN report by USDA Foreign Agricultural Service. Retrieved from https:/gain.fas.usda.gov/ Recent\%20GAIN\%20Publications/Overview\%20on\%20the\%20German\%20 Wine\%20Sector_Berlin_Germany_2-11-2015.pdf

12. MAFWE (2010). Draft vine and wine sector strategy 2010-2015. Retrieved from https://agencija.gov.mk/download/\%D0\%A $\%$ D0 $\% \mathrm{~B} 5 \% \mathrm{D} 0 \% \mathrm{~B} 3 \% \mathrm{D}$ $1 \% 83 \%$ D0\%BB\%D0\%B0\%D1\%82\%D0\%B8\%D0\%B2\%D0\%B0/272053 4313Nacrtstrategijazalozarstvoivinarstvo_2010-2015.pdf [in Macedonian: Министерство за земјоделство, шумарство и водостопанство (2010), Нацрт стратегија за лозарство и винарство 2010-2015].

13. Meininger's WBI (2013). A look at the Danish market. Meininger's WBI, pp. 14-16. Retrieved from http:/www.vinavisen.dk/vinavisen/website.nsf/e8aae6 8c888fdba5c12577f6003f2ed1/63a5ff33d2e766aec1257c48004c1676/\$FILE/ WBI_613_p14-16_marketwatch_denmark.pdf

14. Trade map (2017). Retrieved from http://trademap.org

15. Wine Industry. (2015, September 2). Retrieved from http://winesofmacedonia. $\mathrm{mk} /$ wine-industry/

16. Wine Institute (2015). Per capita wine consumption by country 2014. Retrieved from https://www.wineinstitute.org/files/World_Per_Capita_Wine_Consumption_Revised_Nov_2015.pdf

17. Wine Institute (2017). World wine consumption by country $2013-2015$ and \% change 2015/2013, liters (000). Retrieved from http://www.wineinstitute.org/ files/World_Wine_Consumption_by_Country_2015.pdf

18. WOM (2015). Strategic plan 2015-2020. WOM. Skopje. Republic of Macedonia

19. WOM (2017b). PPT Export of Wine in 2016. WOM. Skopje. Republic of Macedonia

20. WOM (2017c). Wine Export Report in 2016. WOM. Skopje. Republic of Macedonia

21. WOM (2017d). Wine Export by Country 2010 - 2016. WOM. Skopje. Republic of Macedonia

22. WOM (2017a). Wine Export Comparative Analysis 2010 - 2016. WOM. Skopje. Republic of Macedonia 